\title{
Peripartal Metabolism and Production of Holstein Cows Fed Diets Supplemented with Fat During the Dry Period*
}

\author{
G. N. Douglas,† T. R. Overton,† H. G. Bateman II,§ and J. K. Drackley \\ Department of Animal Sciences, University of Illinois, Urbana 61801
}

\begin{abstract}
Previous research from our laboratory demonstrated that cows fed supplemental fat throughout the dry period in an attempt to increase body condition score (BCS) had little hepatic lipid accumulation at d 1 postpartum compared with cows fed an isocaloric high-grain diet or a lower energy control diet. However, results were confounded by lower dry matter intake and loss of BCS by cows fed the fat-supplemented diet. Here, cows were fed a control diet (C) moderately high in nonfiber carbohydrates (NFC) or an isocaloric fat-supplemented, low NFC (F) diet to reassess the effects of supplemental fat throughout the dry period on peripartal lipid accumulation in liver. A more energy-dense, high-NFC diet supplemented with fat (CF) was also fed to test the efficacy of supplemental fat in a diet with similar carbohydrate composition but higher energy density. Intakes of dry matter and net energy for lactation were similar among treatments throughout the experiment, although diet $\times$ day interactions during the last $21 \mathrm{~d}$ before parturition indicated that cows fed $\mathrm{CF}$ decreased intakes more slowly. Cows gained similar amounts of BCS and body weight among diets prepartum, but cows fed $\mathrm{C}$ tended to lose more BCS and body weight around parturition. Milk production and milk components did not differ among treatments. Prepartum concentrations of glucose, insulin, total protein, nonesterified fatty acids, and $\beta$-hydroxybutyrate in plasma were similar among treatments. Supplemental fat increased prepartum concentrations of urea and cholesterol in plasma. Postpartum concentrations of metabolites and insulin in plasma were similar among
\end{abstract}

Received April 28, 2004.

Accepted August 11, 2004.

Corresponding author: J. K. Drackley; e-mail: drackley@uiuc.edu.

*This project was funded by a grant from the Fats and Proteins Research Foundation and USDA Section 1433 Animal Health and Disease Funds appropriated to the Illinois Agricultural Experiment Station.

$\dagger$ Current address: CPO 1862, Berea College, Berea, KY 40404.

†Department of Animal Science, Cornell University, Ithaca, NY 14853.

$\S$ Department of Dairy Science, Louisiana State University, Baton Rouge, LA 70803. treatments. Concentrations of total lipid and triglyceride in liver increased at parturition, whereas hepatic glycogen concentration decreased, but concentrations were not different among treatments. Supplemental fat fed prepartum did not affect peripartal lipid accumulation in liver tissue and did not benefit postpartum milk production.

(Key words: dry period, energy, liver, supplemental fat)

Abbreviation key: $\mathbf{C}=$ moderate-NFC control diet, $\mathbf{C F}=$ moderate-NFC, fat-supplemented diet, $\mathbf{F}=$ lowNFC, fat-supplemented diet, LCFA = long-chain fatty acids, $\mathbf{T G}=$ triglyceride.

\section{INTRODUCTION}

Appropriate nutrition and management strategies during the dry period to minimize health disorders and maximize subsequent productivity at the next parturition remain controversial and poorly defined (Drackley, 1999). Strategies that prevent excessive body lipid mobilization and result in lower lipid accumulation in liver around parturition are believed to be desirable because of the association between hepatic lipid accumulation and periparturient disorders (Grummer, 1993; Rukkwamsuk et al., 1998; Drackley et al., 2001).

In previous research from our laboratory, feeding a diet supplemented with fat in an attempt to add BCS to thin cows during the dry period was associated with marked decreases in concentrations of total lipid and triglyceride (TG) in liver tissue obtained at d 1 postpartum (Grum et al., 1996b). At d 1 postpartum, rates of peroxisomal $\beta$-oxidation of palmitate in homogenates of liver tissue were greater, and rates of palmitate esterification in liver slices were less, for cows fed the fatsupplemented diet compared with those fed an isocaloric low-fat diet or a lower energy control diet during the dry period (Grum et al., 1996b). Therefore, dietary fat might alter liver metabolism to contend with the marked peripartal increases in blood NEFA (Grum et al., 1996b; Drackley, 1999) that can lead to the development of fatty liver (Morrow, 1976). However, poor forage quality and high content of rumen-active fat (mainly choice white grease) in the fat-supplemented 
diet fed by Grum et al. (1996b) resulted in significantly lower DMI and BCS loss rather than gain during the dry period, leaving the effects of dietary fat throughout the dry period unresolved.

In contrast to results of Grum et al. (1996b), others have suggested that supplemental fat might increase the risk of peripartal lipid accumulation in the liver of dairy cows (Skaar et al., 1989; Vazquez-Añon et al., 1997). Some dietary long-chain fatty acids (LCFA) can enter the ruminant liver by specific pathways (Grum et al., 1996a; Drackley, 1999), although lymphatic transport of dietary lipids and low activity of hepatic lipase in ruminant liver (Emery et al., 1992) should limit the amount of dietary LCFA taken up by the liver and thereby minimize any significant contribution to the development of hepatic lipidosis.

Because of the confounding of diet composition and nutrient intakes in the study by Grum et al. (1996b), effects of supplemental rumen-active fat during the dry period remain uncertain and demand corroboration. The hypothesis tested in this experiment was that, if the additional fat per se was responsible for the prevention of total lipid and TG accumulation in the liver around parturition in the study by Grum et al. (1996b), then addition of the same fat to diets differing in ingredient composition and nutrient density should have repeatable and similar effects. Therefore, the objective of our study was to determine the effects of supplemental fat in dry cow diets with differing caloric densities on hepatic TG accumulation and other aspects of peripartal metabolism. Dietary treatments were designed in an effort to prevent the confounding effects of decreased DMI that occurred in the previous experiment (Grum et al., 1996b). Effects of diets on prepartum and postpartum DMI and performance also were determined.

\section{MATERIALS AND METHODS}

\section{Cows, Diets, and Experimental Design}

All procedures were conducted under protocols approved by the University of Illinois Laboratory Animal Care Advisory Committee. Thirty-six Holstein cows were dried off $60 \mathrm{~d}$ before their expected parturition date and were then immediately and sequentially assigned to 1 of 3 dietary treatment groups. Cows were chosen for the experiment based on BCS $\leq 3.5$ ( 1 to 5 scale; Wildman et al., 1982) so that addition of BCS before calving might be desirable (Grum et al., 1996b). Diets were fed throughout the dry period as in the study by Grum et al. (1996b) to allow BCS gain.

Diets were designed to test the same supplemental fat source as used in our previous study (Grum et al., 1996b), but in a lower amount and in diets of higher quality in an effort to minimize any fat-induced de-
Table 1. Ingredient composition of diets fed to dry and lactating cows.

\begin{tabular}{|c|c|c|c|c|}
\hline \multirow[b]{2}{*}{ Ingredient } & \multicolumn{4}{|c|}{$\operatorname{Diet}^{1}$} \\
\hline & $\mathrm{C}$ & $\mathrm{F}$ & $\mathrm{CF}$ & Lactation \\
\hline & \multicolumn{4}{|c|}{$\longrightarrow(\%$ of $\mathrm{DM})$} \\
\hline Alfalfa silage & 50.00 & 50.00 & 50.00 & 26.00 \\
\hline Corn silage & 25.00 & 25.00 & 25.00 & 26.00 \\
\hline Ground shelled corn & 15.00 & 3.00 & 11.95 & 24.75 \\
\hline Soybean meal & 1.70 & 4.03 & 2.60 & 14.50 \\
\hline Soybean hulls & 7.58 & 1.19 & 5.70 & 4.00 \\
\hline Oat hulls & $\ldots$ & 12.00 & & \\
\hline Liquid fat ${ }^{2}$ & & 4.00 & 4.00 & 2.00 \\
\hline Mineral-vitamin premix ${ }^{3}$ & 0.15 & 0.15 & 0.15 & 0.15 \\
\hline Limestone & $\ldots$ & . & & 1.00 \\
\hline Sodium bicarbonate & $\ldots$ & & & 0.75 \\
\hline Magnesium oxide & 0.05 & 0.05 & 0.05 & 0.15 \\
\hline Monosodium phosphate & 0.32 & 0.38 & 0.35 & \\
\hline Dicalcium phosphate & & $\ldots$ & $\ldots$ & 0.50 \\
\hline Salt (plain) & 0.20 & 0.20 & 0.20 & 0.20 \\
\hline
\end{tabular}

${ }^{1} \mathrm{C}=$ Moderate NFC; $\mathrm{F}$ = low NFC, fat-supplemented $\mathrm{CF}=$ moderate NFC, fat-supplemented.

${ }^{2}$ Qual-Fat (National By-Products, Inc., Mason City, IL).

${ }^{3}$ Contained $5.0 \% \mathrm{Mg}, 7.5 \% \mathrm{~K}, 10.0 \% \mathrm{~S}, 0.5 \% \mathrm{Na}, 3.0 \% \mathrm{Cl}, 3.0 \% \mathrm{Zn}$, $3.0 \% \mathrm{Mn}, 2.0 \% \mathrm{Fe}, 0.5 \% \mathrm{Cu}, 0.015 \% \mathrm{Se}, 0.004 \% \mathrm{Co}, 0.025 \% \mathrm{I}, 1000$ $\mathrm{IU} / \mathrm{g}$ of vitamin $\mathrm{A}, 300 \mathrm{IU} / \mathrm{g}$ vitamin $\mathrm{D}$, and $3.5 \mathrm{IU} / \mathrm{g}$ of vitamin $\mathrm{E}$.

creases in DMI as observed previously. Dry period diets (Table 1) consisted of 1) a moderate-NFC control diet (C), 2) a low-NFC, fat-supplemented $\operatorname{diet}(\mathbf{F})$, and 3) a moderate-NFC, fat-supplemented (CF) diet. Diets were based on alfalfa silage and corn silage. The rumenactive fat source (Qual-Fat; National By-Products, Mason City, IL) consisted mainly of choice white grease. The LCFA composition as determined by GLC of methyl esters (Sukhija and Palmquist, 1988) was $3.1 \% \mathrm{C}_{14: 0}$, $0.9 \% \mathrm{C}_{14: 1}, 24.2 \% \mathrm{C}_{16: 0}, 4.9 \% \mathrm{C}_{16: 1}, 0.3 \% \mathrm{C} 17: 0,13.8 \%$ $\mathrm{C}_{18: 0}, 46.2 \%$ cis- $\mathrm{C}_{18: 1}, 6.1 \% \mathrm{C}_{18: 2}$, and $0.4 \% \mathrm{C}_{18: 3}$. The fat had a calculated iodine value of 61 and a FFA content of $6.6 \%$.

All diets were fed as TMR for ad libitum intake throughout the dry period. Diets $\mathrm{C}$ and $\mathrm{F}$ were formulated according to NRC (1989) to provide adequate energy for a nonlactating $650-\mathrm{kg}$ cow consuming $12 \mathrm{~kg}$ of $\mathrm{DM} / \mathrm{d}$ to gain about $36 \mathrm{~kg}$ of BW during the dry period in excess of fetal growth. Assuming that 1 BCS unit equals $56 \mathrm{~kg}$ (Otto et al., 1991), this BW gain would translate to a potential increase of approximately 0.6 BCS units during the dry period. Diet $\mathrm{F}$ was maintained isocaloric to $\mathrm{C}$ by substituting oat hulls for appropriate amounts of ground shelled corn and soybean hulls. Diets $\mathrm{C}$ and $\mathrm{F}$ allowed determination of effects of fat supplementation in diets of similar energy density and with the same forage content, albeit with differing concentrate carbohydrates. Diet $\mathrm{CF}$ was formulated by supplementing the same amount of fat as in $\mathrm{F}$ to the dietary components in $\mathrm{C}$; consequently, $\operatorname{diet} \mathrm{CF}$ was 
Table 2.. Ingredient composition of diets fed to dry cows from $2 \mathrm{wk}$ before expected parturition until calving.

\begin{tabular}{|c|c|c|c|}
\hline \multirow[b]{2}{*}{ Ingredient } & \multicolumn{3}{|c|}{$\operatorname{Diet}^{1}$} \\
\hline & $\mathrm{C}$ & $\mathrm{F}$ & $\mathrm{CF}$ \\
\hline & & $\%$ of $\mathrm{DN}$ & \\
\hline Alfalfa silage & 45.45 & 45.45 & 45.45 \\
\hline Corn silage & 22.73 & 22.73 & 22.73 \\
\hline Ground shelled corn & 13.64 & 2.73 & 10.86 \\
\hline Soybean meal & 1.55 & 3.66 & 2.36 \\
\hline Soybean hulls & 6.89 & 1.08 & 5.19 \\
\hline Oat hulls & $\ldots$ & 10.91 & \\
\hline Liquid fat $^{2}$ & $\ldots$ & 3.64 & 3.64 \\
\hline Mineral-vitamin premix ${ }^{3}$ & 0.14 & 0.14 & 0.14 \\
\hline Magnesium oxide & 0.04 & 0.04 & 0.04 \\
\hline Monosodium phosphate & 0.29 & 0.35 & 0.32 \\
\hline Salt (plain) & 0.18 & 0.18 & 0.18 \\
\hline Anionic salt mixture ${ }^{4}$ & 9.09 & 9.09 & 9.09 \\
\hline
\end{tabular}

${ }^{1} \mathrm{C}=$ Moderate NFC; $\mathrm{F}=$ low NFC, fat-supplemented $; \mathrm{CF}=$ moderate NFC, fat-supplemented.

${ }^{2}$ Qual-Fat (National By-Products, Inc., Mason City, IL).

${ }^{3}$ Contained $5.0 \% \mathrm{Mg}, 7.5 \% \mathrm{~K}, 10.0 \% \mathrm{~S}, 0.5 \% \mathrm{Na}, 3.0 \% \mathrm{Cl}, 3.0 \% \mathrm{Zn}$, $3.0 \% \mathrm{Mn}, 2.0 \% \mathrm{Fe}, 0.5 \% \mathrm{Cu}, 0.015 \% \mathrm{Se}, 0.004 \% \mathrm{Co}, 0.025 \% \mathrm{I}, 1000$ $\mathrm{IU} / \mathrm{g}$ of vitamin A, $300 \mathrm{IU} / \mathrm{g}$ vitamin $\mathrm{D}$, and $3.5 \mathrm{IU} / \mathrm{g}$ of vitamin $\mathrm{E}$.

${ }^{4}$ Contained a maximum content of $5 \%$ crude fiber, minimum contents of $10 \% \mathrm{CP}$ and $1 \%$ ether extract, $2.5 \% \mathrm{Mg}, 3.2 \% \mathrm{~S}, 0.43 \% \mathrm{~K}$, $16.5 \% \mathrm{Cl}, 0.0007 \% \mathrm{Se}, 110 \mathrm{IU} / \mathrm{g}$ vitamin $\mathrm{A}, 44 \mathrm{IU} / \mathrm{g}$ vitamin $\mathrm{D}, 1.32$ $\mathrm{IU} / \mathrm{g}$ vitamin $\mathrm{E}$, and $13.2 \mathrm{mg} / \mathrm{g}$ niacin.

more energy dense than either $\operatorname{diet} \mathrm{C}$ or $\operatorname{diet} \mathrm{F}$. Comparison of diets $\mathrm{C}$ and $\mathrm{CF}$ tested the effect of fat addition in the presence of similar carbohydrate composition and at higher energy density. It was not our intent to make comparisons of diets differing in energy density or to test the interaction of fat inclusion and basal diet energy density; therefore, comparisons were made only to diet $\mathrm{C}$ to determine whether the fat-supplemented diets altered response variables.

Cows were housed in tie stalls throughout the experiment and were allowed to exercise daily in an outside lot from 0600 to $0930 \mathrm{~h}$. Two weeks before expected parturition, cows were moved to maternity box stalls until parturition. During this time, a premix containing anionic salts from fermentation byproducts was added to each of the dry period diets at approximately $9 \%$ of total dietary DM. The resulting ingredient formulation is shown in Table 2. After parturition, all cows were offered a single lactation diet (Table 1) that contained $2.0 \%$ supplemental fat, and postpartum production was measured for $105 \mathrm{~d}$. Individual DMI was measured daily; BW and BCS were measured weekly. The BCS were assigned by 2 individuals independently. Health records were maintained for all cows, and calf birth weights were recorded.

The number of cows per treatment was determined through power analysis (Morris, 1999) for the primary response variables, which were concentrations of total lipid and TG in liver tissue. In the study of Grum et al. (1996b), mean concentrations of TG in liver (wet weight basis) at $d 1$ postpartum were 1.4, 7.3, and 5.9\% for cows fed the fat-supplemented diet, control diet, and high-grain diet, respectively. Thus, the smallest difference between treatments (4.5 percentage units) was $>90 \%$ of the overall mean TG content. Assuming similar variances as measured in that study, a difference of 3 percentage units ( $60 \%$ difference) in hepatic TG concentration could be detected at $P<0.05$ with 9 cows per treatment. By using 12 cows per treatment in the present study, we determined that we had a $90 \%$ chance to detect a difference in hepatic TG among groups of $50 \%$ with $P<0.05$.

\section{Sampling and Analysis of Feed and Milk}

The TMR components were sampled weekly and dried at $105^{\circ} \mathrm{C}$ for determination of $\mathrm{DM}$ for ration adjustments. Samples of TMR components and complete TMR were obtained weekly and composited monthly. Composite samples were analyzed for contents of DM, $\mathrm{CP}, \mathrm{ADF}, \mathrm{NDF}$, and minerals $(\mathrm{Ca}, \mathrm{P}, \mathrm{Mg}$, and $\mathrm{K})$ by a commercial laboratory (Dairy One, Ithaca, NY). The $\mathrm{NE}_{\mathrm{L}}$ of the dietary components was calculated using equations from the NRC (1989). Ether extract was analyzed according to standard procedures (AOAC, 1990).

Milk weights were recorded daily and samples were obtained once weekly from consecutive a.m. and p.m. milkings. Samples were composited in proportion to milk production at each sampling and were preserved with 2-bromo-2-nitropropane-1,3-diol. Composite samples were analyzed for fat and CP contents by infrared analysis (Dairy Laboratory Services, Dubuque, IA).

\section{Sampling and Analysis of Liver and Blood}

Puncture biopsy was performed under local anesthesia to obtain approximately 3 to $5 \mathrm{~g}$ of liver tissue (Drackley et al., 1991) at -65 and $-21 \mathrm{~d}$ relative to expected parturition and at 1,21, and $65 \mathrm{~d}$ after parturition. Aliquots of liver tissue were frozen immediately in liquid $\mathrm{N}_{2}$ until later analysis for contents of total lipid (Drackley et al., 1991), TG (Foster and Dunn, 1973), and glycogen (Lo et al., 1970).

Blood was sampled from the coccygeal vein or artery beginning at $0900 \mathrm{~h}$; all sampling was completed before the morning dispensation of TMR. During the dry period, blood was sampled once weekly for $30 \mathrm{~d}$ after dryoff, twice weekly during wk -4 and -3 , and 3 times weekly during wk -2 and -1 before expected parturition. After calving, blood was sampled 3 times weekly during wk 1 and 2 and twice weekly during wk 3 and 4 , relative to parturition; thereafter, blood was sampled once weekly until $105 \mathrm{~d}$ postpartum. 
Blood samples were collected in evacuated test tubes (Vacutainer; Becton Dickinson, Rutherford, NJ) containing sodium heparin. Plasma was obtained via centrifugation and aliquots were frozen at $-20^{\circ} \mathrm{C}$ until later analysis for concentrations of NEFA (johnson and Peters, 1993), glucose (Trinder, 1969; kit number 315, Sigma Chemical Co., St. Louis, MO), and urea (Crocker, 1967; kit number 535, Sigma). Concentrations of BHBA (Williamson and Mellanby, 1974; kit number 310, Sigma) and total protein (Weichselbaum, 1945; total protein kit, Roche Diagnostics, Inc., Indianapolis, IN) in plasma were determined by enzymatic assays using an autoanalyzer (Hitachi 911; Roche Diagnostics). Cholesterol was determined using cholesterol esterase and cholesterol oxidase (Allain et al., 1974) coupled to the Trinder color development reaction (Trinder, 1969; cholesterol/HP kit, Roche Diagnostics) in an autoanalyzer. Concentrations of insulin in plasma were determined using a radioimmunoassay kit (Coat-a-Count Insulin kit; Diagnostic Products Inc., Los Angeles, CA) as modified by Studer et al. (1993).

\section{Statistical Analysis}

Data were subjected to ANOVA for a repeated measures design by using the MIXED procedure of SAS (SAS, 1998). The model contained the effects of dietary treatment ( C, F, or CF), cow nested within dietary treatment, time (as a repeated factor), and the interaction of diet and time; cow nested within treatment was designated a random effect and was used as the error term to test the effect of dietary treatments. The covariance structure for the repeated effect of time (week or day) was modeled using the AR(1) option of SAS. The model for BCS analysis also contained the effects of scorer. Treatment effects were separated by use of nonorthogonal contrasts for 1 ) the effect of adding fat so that energy density was increased (C vs. CF), and 2) the effect of substituting fat for concentrate ingredients to maintain energy density (C vs. F).

Separate ANOVA were conducted for intakes of DM and $\mathrm{NE}_{\mathrm{L}}$ during the prepartum period ( $-60 \mathrm{~d}$ relative to expected calving to $-1 \mathrm{~d}$ relative to actual calving), prepartum transition period ( $3 \mathrm{wk}$ before expected calving to $-1 \mathrm{~d}$ relative to actual calving), postpartum transition period (calving to $3 \mathrm{wk}$ after calving), and postpartum period (calving to $105 \mathrm{~d}$ after calving). Separate ANOVA were conducted for BW and BCS data that were recorded during the prepartum and postpartum periods only. For concentrations of glucose, insulin, NEFA, cholesterol, BHBA, total protein, and urea in plasma, separate ANOVA were conducted for the entire prepartum period, the transition period ( $21 \mathrm{~d}$ before the expected calving date to $21 \mathrm{~d}$ after the actual calv- ing), and the entire postpartum period. Concentrations of glucose, insulin, NEFA, cholesterol, BHBA, total protein, and urea in plasma were adjusted by analysis of covariance using the respective data obtained before dry-off at $-65 \mathrm{~d}$ relative to expected parturition. The contents of total lipid, TG, and glycogen in liver during the prepartum and postpartum periods were combined for analysis; these data also were adjusted by analysis of covariance using the respective data obtained before dry-off at $-65 d$ relative to expected parturition. The incidences of health problems recorded during the study, including displaced abomasum, ketosis, mastitis, metritis, milk fever, and retained placenta, were subjected to $\chi^{2}$ analysis to determine whether incidences differed among treatment groups.

Because one cow was determined not to be pregnant immediately before expected parturition, it was eliminated from the experiment; therefore, $n=11$ for $\mathrm{C}, \mathrm{n}=$ 12 for $\mathrm{F}$, and $\mathrm{n}=12$ for $\mathrm{CF}$. Least square means were computed (SAS, 1998) and are presented throughout. Significance was declared at $P \leq 0.05$ and trends discussed when $P>0.05$ but $P<0.15$.

\section{RESULTS AND DISCUSSION}

Diets were fed for a mean of $57 \pm 7 \mathrm{~d}$ before parturition. Chemical composition of the diets is shown in Tables 3 and 4 . Diets $\mathrm{C}$ and $\mathrm{F}$ were formulated to be isocaloric; calculated energy content based on actual chemical analyses averaged 1.45 and $1.47 \mathrm{Mcal}$ of $\mathrm{NE}_{\mathrm{L}}$ per kg of DM (Table 3). Diet CF, formulated to represent a practical diet that was similar to $\mathrm{C}$ but with supplemental fat, had an increased $\mathrm{NE}_{\mathrm{L}}$ density $(1.60 \mathrm{Mcal} /$ $\mathrm{kg}$ of DM; Table 3). However, intakes of $\mathrm{DM}$ and $\mathrm{NE}_{\mathrm{L}}$ were not statistically different among treatments during the dry period (Table 5). Dry cows fed C, F, and CF had mean DMI of $14.1,15.2$, and $13.9 \mathrm{~kg} / \mathrm{d}$, or 2.11 , 2.36 , and $2.10 \%$ of their BW at dry-off. Nonetheless, the slightly lower DMI for dry cows fed the more energydense dry diet $(\mathrm{CF})$ resulted in similar intakes of $\mathrm{NE}_{\mathrm{L}}$ when compared with those for cows fed $\mathrm{C}$ and $\mathrm{F}$.

As calving approached, intakes of DM (Figure 1A) and $\mathrm{NE}_{\mathrm{L}}$ (Figure $1 \mathrm{~B}$ ) steadily decreased, but no differences were noted among treatments for average intakes of $\mathrm{DM}$ and $\mathrm{NE}_{\mathrm{L}}$ during the prepartum transition period. Significant diet $\times$ day interactions were detected for intakes of DM $(P<0.01)$ and $\mathrm{NE}_{\mathrm{L}}(P<0.01)$ during the prepartum transition period. To discern the nature of these interactions, we examined the simple linear regressions across days within treatments. Regression coefficients, representing average daily rate of DMI decline, were $53 \%$ greater for C $(-0.35 \mathrm{~kg} / \mathrm{d})$ and $41 \%$ greater for $\mathrm{F}(-0.32 \mathrm{~kg} / \mathrm{d})$ than for CF $(-0.23 \mathrm{~kg} / \mathrm{d})$. For $\mathrm{NE}_{\mathrm{L}}$ intake, regression coefficients were $38 \%$ greater 
Table 3. Chemical composition ${ }^{1}$ and standard deviations of diets fed to dry and lactating cows.

\begin{tabular}{|c|c|c|c|c|}
\hline \multirow[b]{2}{*}{ Component } & \multicolumn{4}{|c|}{ Diet $^{2}$} \\
\hline & $\mathrm{C}$ & $\mathrm{F}$ & $\mathrm{CF}$ & Lactation \\
\hline $\mathrm{DM}, \%$ & $63.68 \pm 2.87$ & $64.67 \pm 2.62$ & $64.20 \pm 2.86$ & $69.47 \pm 1.33$ \\
\hline & & & & \\
\hline $\begin{array}{l}\mathrm{CP} \\
\mathrm{ADF}\end{array}$ & $\begin{array}{l}13.25 \pm 0.74 \\
32.05 \pm 1.17\end{array}$ & $\begin{array}{l}12.85 \pm 0.67 \\
33.27 \pm 1.33\end{array}$ & $\begin{array}{l}13.09 \pm 0.78 \\
31.01 \pm 1.56\end{array}$ & $\begin{array}{l}17.25 \pm 0.73 \\
20.94 \pm 1.63\end{array}$ \\
\hline NDF & $43.36 \pm 2.44$ & $47.13 \pm 2.28$ & $41.80 \pm 2.60$ & $30.27 \pm 2.00$ \\
\hline $\mathrm{NFC}^{3}$ & $36.38 \pm 3.06$ & $23.72 \pm 2.90$ & $31.06 \pm 4.60$ & $40.08 \pm 1.77$ \\
\hline $\mathrm{NE}_{\mathrm{L}},{ }^{4} \mathrm{Mcal} / \mathrm{kg} \mathrm{DM}$ & $1.45 \pm 0.02$ & $1.47 \pm 0.02$ & $1.60 \pm 0.02$ & $1.74 \pm 0.02$ \\
\hline $\mathrm{NE}_{\mathrm{L}}{ }^{5} \mathrm{Mcal} / \mathrm{kg} \mathrm{DM}$ & $1.50 \pm 0.02$ & $1.51 \pm 0.02$ & $1.62 \pm 0.02$ & $1.67 \pm 0.02$ \\
\hline $\mathrm{Ca}$ & $0.68 \pm 0.02$ & $0.66 \pm 0.03$ & $0.68 \pm 0.02$ & $0.98 \pm 0.07$ \\
\hline $\mathrm{P}$ & $0.35 \pm 0.02$ & $0.36 \pm 0.03$ & $0.36 \pm 0.02$ & $0.42 \pm 0.02$ \\
\hline $\mathrm{Mg}$ & $0.23 \pm 0.01$ & $0.21 \pm 0.01$ & $0.22 \pm 0.01$ & $0.28 \pm 0.02$ \\
\hline $\mathrm{K}$ & $1.73 \pm 0.19$ & $1.71 \pm 0.18$ & $1.70 \pm 0.19$ & $1.54 \pm 0.11$ \\
\hline $\mathrm{Na}$ & $0.15 \pm 0.02$ & $0.16 \pm 0.03$ & $0.16 \pm 0.03$ & $0.32 \pm 0.03$ \\
\hline Ether extract & $2.76 \pm 0.24$ & $6.40 \pm 0.72$ & $6.67 \pm 0.81$ & $4.65 \pm 0.32$ \\
\hline
\end{tabular}

${ }^{1}$ Calculated from monthly analyses of individual ingredients in rations.

${ }^{2} \mathrm{C}=$ Moderate NFC; $\mathrm{F}=$ low NFC, fat-supplemented; $\mathrm{CF}=$ moderate NFC, fat-supplemented.

${ }^{3} \mathrm{NFC}=100-\mathrm{NDF} \%-\mathrm{CP} \%-$ ether extract $\%-$ ash $\%$.

${ }^{4}$ Calculated by Dairy One Laboratory (Ithaca, NY) using NRC (1989) energy equations; these values were used in calculation of energy intakes.

${ }^{5}$ Calculated from model in NRC (2001).

for $\mathrm{C}(-0.50 \mathrm{Mcal} / \mathrm{d})$ and $32 \%$ greater for $\mathrm{F}(-0.47 \mathrm{Mcal} /$ d) than for $\mathrm{CF}$ ( $-0.36 \mathrm{Mcal} / \mathrm{d})$. We interpret these data to indicate that increasing dietary energy density with supplemental fat slowed the rate of prepartum decline in both $\mathrm{DMI}$ and $\mathrm{NE}_{\mathrm{L}}$ intake and therefore might facilitate maintenance of prepartal DMI and $\mathrm{NE}_{\mathrm{L}}$ intake.

Table 4. Chemical composition ${ }^{1}$ and standard deviations of diets fed to dry cows from 2 wk before expected parturition until calving.

\begin{tabular}{lrrr}
\hline & \multicolumn{3}{c}{ Diet $^{2}$} \\
\cline { 2 - 4 } Component & \multicolumn{1}{c}{$\mathrm{C}$} & \multicolumn{1}{l}{$\mathrm{F}$} \\
\hline $\mathrm{DM}, \%$ & $66.22 \pm 2.99$ & $67.23 \pm 2.77$ & $66.70 \pm 2.98$ \\
$\mathrm{CP}$ & $13.19 \pm 0.79$ & $12.72 \pm 0.77$ & $13.06 \pm 0.82$ \\
$\mathrm{ADF}$ & $30.06 \pm 1.26$ & $31.22 \pm 1.33$ & $28.97 \pm 1.34$ \\
$\mathrm{NDF}$ & $41.51 \pm 2.31$ & $44.74 \pm 1.97$ & $39.90 \pm 2.26$ \\
$\mathrm{NFC}^{3}$ & $36.38 \pm 2.99$ & $22.09 \pm 2.19$ & $28.93 \pm 2.82$ \\
$\mathrm{NE}_{\mathrm{L}}{ }^{4}{ }^{4} \mathrm{Mcal} / \mathrm{kg} \mathrm{DM}$ & $1.48 \pm 0.03$ & $1.47 \pm 0.02$ & $1.61 \pm 0.03$ \\
$\mathrm{NE}_{\mathrm{L}},{ }^{\mathrm{M}} \mathrm{Mcal} / \mathrm{kg} \mathrm{DM}$ & $1.52 \pm 0.03$ & $1.51 \pm 0.02$ & $1.62 \pm 0.03$ \\
$\mathrm{Ca}$ & $0.63 \pm 0.02$ & $0.61 \pm 0.02$ & $0.62 \pm 1.09$ \\
$\mathrm{P}$ & $0.32 \pm 0.02$ & $0.33 \pm 0.03$ & $0.33 \pm 0.02$ \\
$\mathrm{Mg}$ & $0.44 \pm 0.01$ & $0.42 \pm 0.01$ & $0.43 \pm 0.01$ \\
$\mathrm{~K}$ & $1.65 \pm 0.21$ & $1.62 \pm 0.20$ & $1.63 \pm 0.22$ \\
$\mathrm{Na}$ & $0.13 \pm 0.02$ & $0.15 \pm 0.02$ & $0.15 \pm 0.02$ \\
Ether extract & $2.81 \pm 0.32$ & $6.36 \pm 0.76$ & $6.59 \pm 0.64$ \\
\hline
\end{tabular}

${ }^{1}$ Calculated from monthly analyses of individual ingredients in rations.

${ }^{2} \mathrm{C}=$ Moderate NFC; $\mathrm{F}=$ low NFC, fat-supplemented $\mathrm{CF}$ = moderate $\mathrm{NFC}$, fat-supplemented.

${ }^{3} \mathrm{NFC}=100-\mathrm{NDF} \%-\mathrm{CP} \%-$ ether extract $\%-$ ash $\%$.

${ }^{4}$ Calculated by Dairy One Laboratory (Ithaca, NY) using NRC (1989) energy equations; these values were used in calculation of energy intakes.

${ }^{5}$ Calculated from model in NRC (2001).
Peripartal DMI decreased by an average of $30 \%$ (from 15 to $10 \mathrm{~kg} / \mathrm{d}$ ) across all diets during the last $21 \mathrm{~d}$ before parturition, which is similar to the decreases in DMI by peripartal dairy cows summarized previously by Grummer (1995). In contrast, Grum et al. (1996b) reported that the peripartal decreases in DMI by ad libitum-fed cows were slightly less than $10 \%$, but their diets contained poor quality forage that may have contributed to consistently lower DMI during the dry period compared with those in the present study. Regardless of dry period diet, cows consumed similar amounts of $\mathrm{DM}$ and $\mathrm{NE}_{\mathrm{L}}$ on the day before calving despite the greater energy density of diet CF (Figure 1). Cows fed diet $\mathrm{C}$ seemed to decrease DMI beginning $3 \mathrm{~d}$ before parturition. Postpartum intakes of $\mathrm{DM}$ and $\mathrm{NE}_{\mathrm{L}}$ increased steadily during the first $10 \mathrm{wk}$ of lactation (data not shown). No differences among diets and no diet by day interactions were observed for either variable during the postpartum transition period (Figure 1) or during the first $105 \mathrm{~d}$ of lactation (Table 5).

Diets $\mathrm{C}$ and $\mathrm{F}$ were formulated to allow gains of BCS ( 0.6 BSC units; see Materials and Methods) during the dry period. Gains of BCS and BW (Figure 2) during the dry period were similar among treatments regardless of dietary energy densities, but average BCS gain for all treatments was less than expected. In contrast to our results, Grum et al. (1996b) reported that dry cows fed diets somewhat similar to $\mathrm{F}$ in the present study did not increase BCS; cows fed the high grain diet gained BCS, whereas those fed the fat-supplemented diet lost BCS. Decreases in BCS during the dry 
Table 5. Intakes of $\mathrm{DM}$ and $\mathrm{NE}_{\mathrm{L}}$, calf birth weights, milk production, and milk composition for cows fed different diets throughout the dry period.

\begin{tabular}{|c|c|c|c|c|c|c|}
\hline \multirow[b]{2}{*}{ Variable } & \multicolumn{3}{|c|}{ Diet $^{1}$} & \multirow[b]{2}{*}{ SEM } & \multicolumn{2}{|c|}{ Contrasts $(P)$} \\
\hline & $\mathrm{C}$ & $\mathrm{F}$ & $\mathrm{CF}$ & & $\mathrm{C}$ vs. $\mathrm{CF}$ & C vs. $\mathrm{F}$ \\
\hline \multicolumn{7}{|l|}{ DMI, kg } \\
\hline prepartum $^{2}$ & 14.1 & 15.1 & 13.9 & 0.7 & 0.86 & 0.30 \\
\hline postpartum 3 & 20.0 & 21.1 & 20.9 & 0.8 & 0.43 & 0.32 \\
\hline \multicolumn{7}{|l|}{$\mathrm{NE}_{\mathrm{L}}$ intake, $\mathrm{Mcal} / \mathrm{d}$} \\
\hline prepartum & 20.3 & 22.2 & 22.0 & 1.1 & 0.28 & 0.23 \\
\hline postpartum & 34.3 & 36.6 & 35.9 & 1.5 & 0.46 & 0.28 \\
\hline Calf birth weight, $\mathrm{kg}$ & 43.9 & 43.6 & 43.1 & 1.6 & 0.85 & 0.91 \\
\hline Milk, kg/d & 40.6 & 40.2 & 40.0 & 1.5 & 0.80 & 0.87 \\
\hline Milk fat, $\%$ & 3.35 & 3.37 & 3.50 & 0.14 & 0.43 & 0.88 \\
\hline Milk fat, $\mathrm{kg} / \mathrm{d}$ & 1.36 & 1.36 & 1.41 & 0.07 & 0.67 & 0.96 \\
\hline Milk CP, \% & 3.05 & 3.03 & 3.05 & 0.05 & 0.99 & 0.82 \\
\hline Milk CP, kg/d & 1.26 & 1.25 & 1.24 & 0.06 & 0.75 & 0.84 \\
\hline Milk total solids, $\%$ & 12.17 & 12.19 & 12.40 & 0.28 & 0.33 & 0.92 \\
\hline
\end{tabular}

${ }^{1} \mathrm{C}=$ Moderate NFC; $\mathrm{F}$ = fat-supplemented; $\mathrm{CF}=$ moderate NFC, fat-supplemented.

${ }^{2}$ Mean $=\mathrm{d}-60$ to -1 .

${ }^{3}$ Mean $=\mathrm{d} 1$ to 105 .

period in that study (Grum et al., 1996b) were attributed to decreased DMI of the fat-supplemented diet. In the present study, mean BCS began to decrease about 3 wk before parturition (Figure 2A) as observed by others (Domecq et al., 1997). Mean $\mathrm{NE}_{\mathrm{L}}$ intakes were substantially in excess of calculated $\mathrm{NE}_{\mathrm{L}}$ requirements until the last 1 to $3 \mathrm{~d}$ before parturition. Intakes of $\mathrm{NE}_{\mathrm{L}}$ were calculated using dietary $\mathrm{NE}_{\mathrm{L}}$ values estimated from $\mathrm{NRC}$ (1989) equations; subsequent recalculation of $\mathrm{NE}_{\mathrm{L}}$ using principles and equations in NRC (2001) resulted in slightly higher estimated values for dietary $\mathrm{NE}_{\mathrm{L}}$ content. Use of those higher values obtained from NRC (2001) would exaggerate the apparent discrepancy between adequacy of $\mathrm{NE}_{\mathrm{L}}$ intake and loss of BCS. Loss of BCS may have been attributable at least in part to precalving changes such as relaxation of pelvic ligaments that may have biased visual appraisal of BCS. However, others (VandeHaar et al., 1999; Keady et al., 2001) also have reported prepartum loss of BCS and backfat thickness despite apparently adequate $\mathrm{NE}_{\mathrm{L}}$ intakes. Based on those data, VandeHaar et al. (1999) suggested that prepartal energy requirements might be underestimated; our data would be consistent with that interpretation.

Others have reported that overfeeding cows during the dry period can result in increased BW gains and overconditioning before calving (e.g., Morrow, 1976; Fronk et al., 1980; Rukkwamsuk et al., 1998). However, in many earlier studies, BCS of dry cows was increased by offering dietary components such as grain or corn silage separately from forages, which allowed cows to consume greater amounts of energy throughout or during a large portion of the dry period. In the present study, dry cow diets were fed as TMR, which limited the amounts of NFC and, hence, energy consumed by dry cows regardless of the amounts of energy contained in the diets as NFC or fat. Perhaps more importantly, the BCS of cows nearing parturition were not excessive. Dry cows fed $\mathrm{C}, \mathrm{F}$, and $\mathrm{CF}$ attained maximum means for BCS (Figure 2A) of 3.15, 3.25, and 3.32 on a 1 to 5 scale (Wildman et al., 1982).

Overfeeding during the dry period has been shown to increase the amount of BW loss around and after parturition (Morrow, 1976; Fronk et al., 1980; Reid et al., 1986; Rukkwamsuk et al., 1998), which in turn may increase the susceptibility of cows to peripartal health disorders (Fronk et al., 1980; Treacher et al., 1986; Cameron et al., 1998). Although cows fed CF had higher BCS (Figure 2A) and slightly greater (nonsignificant) mean BW (Figure 2B) during the first $105 \mathrm{~d}$ after calving, cows fed $\mathrm{C}$ tended to lose more BCS (Figure 2A) and $\mathrm{BW}$ (Figure 2B) during the peripartal period than did cows fed F or CF. Data for BCS and BW were not adjusted by analysis of covariance because of unreliable data that were collected before dry-off. Calf birth weights were similar among diets (Table 5).

Milk production (Table 5) did not differ among treatment groups during the first $105 \mathrm{~d}$ of lactation regardless of dry period diet. Milk production steadily increased for all cows (week, $P<0.0001$ ) until wk 6 when it reached a plateau that was maintained through 15 wk of lactation (data not shown). Total solids content as well as contents and yields of fat and total protein in milk did not differ among treatments (Table 5).

The incidences of health problems that required treatment during the experiment are reported in Table 6 . The results from $\chi^{2}$ analyses indicated that the incidences of displaced abomasum, retained placenta, me- 

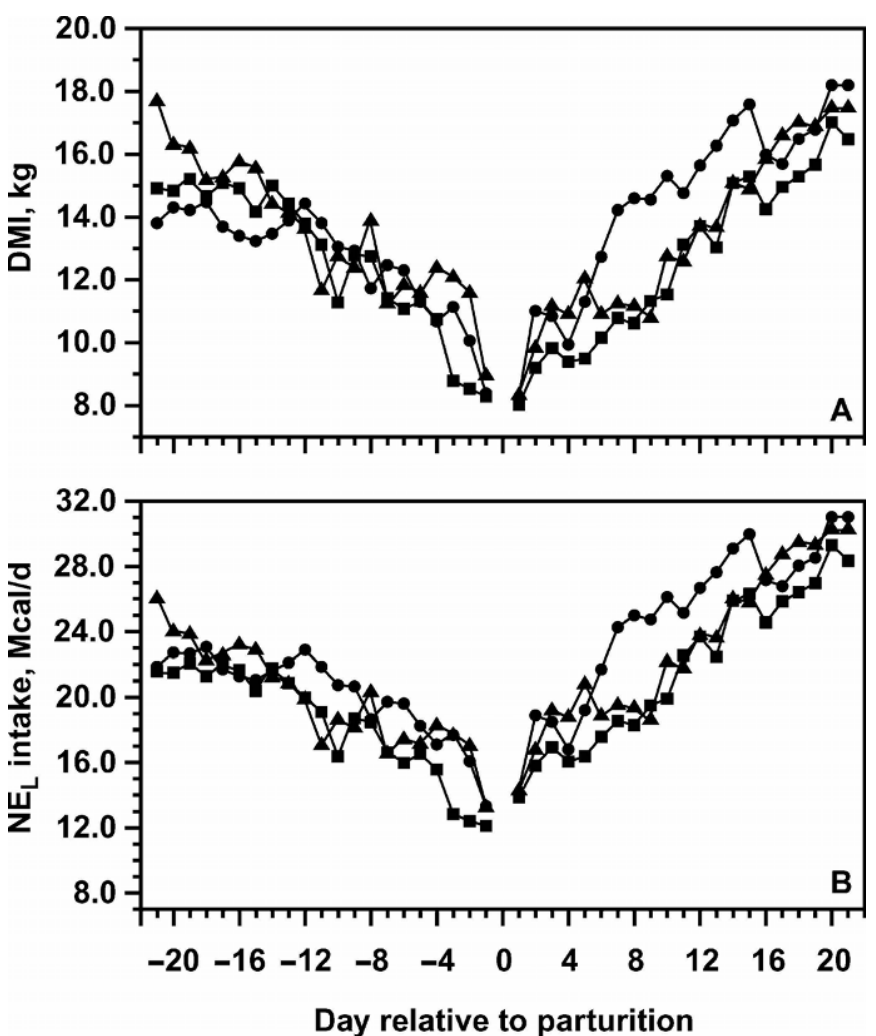

Figure 1. Intakes of $\mathrm{DM}(\mathrm{A})$ and $\mathrm{NE}_{\mathrm{L}}$ (B) during the transition period ( $21 \mathrm{~d}$ before to $21 \mathrm{~d}$ after parturition) for cows fed a control, moderate NFC diet (C; $\mathbf{\square})$, a low NFC diet supplemented with fat $(\mathrm{F} ; \boldsymbol{\Delta})$, or a moderate NFC diet supplemented with fat $(\mathrm{CF} ; \boldsymbol{\bullet})$ during the dry period. A) Prepartum pooled SEM $=1.1 \mathrm{~kg} / \mathrm{d}$; postpartum pooled SEM $=1.6 \mathrm{~kg} / \mathrm{d}$. Effects in the prepartum model included $\mathrm{C}$ vs. $\mathrm{CF}(P=0.99), \mathrm{C}$ vs. $\mathrm{F}(P=0.99)$, day $(P<0.0001)$, and the interaction of diet and day $(P<0.01)$. Effects in the postpartum model included $\mathrm{C}$ vs. $\mathrm{CF}(P=0.29), \mathrm{C}$ vs. F $(P=0.68)$, day $(P<0.0001)$, and the interaction of diet and day $(P=0.88)$. B) Prepartum pooled $\mathrm{SEM}=1.7 \mathrm{Mcal} / \mathrm{d}$; postpartum pooled SEM $=2.8 \mathrm{Mcal} / \mathrm{d}$. Effects in the prepartum model included $\mathrm{C}$ vs. $\mathrm{CF}(P=0.33), \mathrm{C}$ vs. $\mathrm{F}(P=0.42)$ day $(P<0.0001)$, and the interaction of diet and day $(P<0.01)$. Effects in the postpartum model included $\mathrm{C}$ vs. $\mathrm{CF}(P=0.33), \mathrm{C}$ vs. $\mathrm{F}(P=$ $0.65)$, day $(P<0.0001)$, and the interaction of diet and day $(P=0.87)$.

tritis, mastitis, ketosis, and milk fever were similar among treatments. The small number of cows per treatment and the large amount of variation that accompanies peripartal health data demand that these data be interpreted with caution. More extensive studies involving larger numbers of cows per treatment will be required to determine the expected responses to different dry cow feeding strategies on peripartal health in the field.

Concentrations of insulin, glucose, NEFA, and BHBA in plasma did not differ significantly among treatments during the dry period, transition period, or postpartum period (Table 7), although insulin concentrations tended to be lower for cows fed $\mathrm{C}$ during the dry period $(\mathrm{C}$ vs. $\mathrm{CF}, P<0.11)$ and during the transition period $(\mathrm{C}$
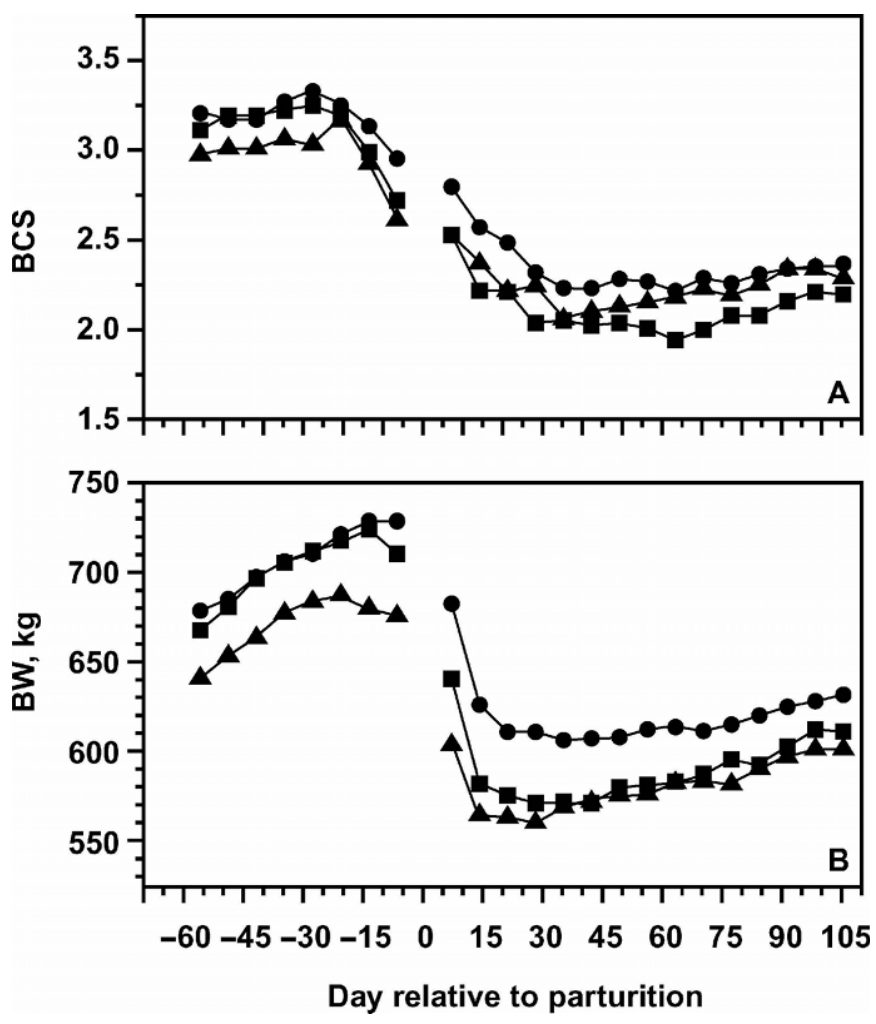

Figure 2. Body condition score (A) and BW (B) for cows fed a control, moderate NFC diet (C; $\mathbf{\square})$, a low NFC diet supplemented with fat $(\mathrm{F} ; \mathbf{\Delta})$, or a moderate NFC diet supplemented with fat (CF; -) during the dry period. A) Prepartum pooled SEM = 0.12 units; postpartum pooled SEM $=0.12$ units. Effects in the prepartum model included $\mathrm{C}$ vs. $\mathrm{CF}(P=0.72), \mathrm{C}$ vs. F $(P=0.55)$, week $(P<0.0001)$, and the interaction of diet and week $(P=0.76)$. Effects in the postpartum model included $\mathrm{C}$ vs. $\mathrm{CF}(P<0.01)$, $\mathrm{C}$ vs. F $(P=0.19)$, week $(P<$ $0.0001)$, and the interaction of diet and week $(P=0.89)$. B) Prepartum pooled $\mathrm{SEM}=17.0 \mathrm{~kg}$; postpartum pooled $\mathrm{SEM}=16.5 \mathrm{~kg}$. Effects in the prepartum model included $\mathrm{C}$ vs. $\mathrm{CF}(P=0.83), \mathrm{C}$ vs. F $(P=0.16)$, week $(P<0.0001)$, and the interaction of diet and week $(P=0.56)$. Effects in the postpartum model included $\mathrm{C}$ vs. $\mathrm{CF}(P=0.17), \mathrm{C}$ vs. $\mathrm{F}(P=0.68)$, week $(P<0.0001)$, and the interaction of diet and week $(P=0.44)$.

Table 6. Frequency ${ }^{1}$ of health disorders for cows fed different diets throughout the dry period.

\begin{tabular}{|c|c|c|c|c|c|}
\hline \multirow[b]{2}{*}{ Disorder } & \multicolumn{3}{|c|}{$\operatorname{Diet}^{1}$} & \multirow[b]{2}{*}{ Chi-square } & \multirow[b]{2}{*}{$P$} \\
\hline & $\mathrm{C}$ & $\mathrm{F}$ & $\mathrm{CF}$ & & \\
\hline Displaced abomasum & 2 & 3 & 2 & 0.29 & 0.86 \\
\hline Retained placenta & 3 & 2 & 4 & 0.89 & 0.64 \\
\hline Metritis & 2 & 0 & 1 & 2.42 & 0.30 \\
\hline Mastitis & 1 & 1 & 4 & 3.37 & 0.19 \\
\hline Ketosis & 3 & 1 & 1 & 2.21 & 0.33 \\
\hline Milk fever & 2 & 2 & 2 & 0.01 & 0.99 \\
\hline Hoof and leg & 2 & 0 & 1 & $\ldots$ & $\ldots$ \\
\hline Twins & 1 & 3 & 1 & $\ldots$ & \\
\hline
\end{tabular}

${ }^{1}$ Number of cows with at least one incidence; individual cows can be reported under more than one disorder.

${ }^{2} \mathrm{C}=$ Moderate NFC; $\mathrm{F}$ = fat-supplemented; $\mathrm{CF}=$ moderate NFC, fat-supplemented. 
Table 7. Concentrations of insulin, glucose, NEFA, BHBA, cholesterol, total protein, and urea in plasma during the prepartum, transition, and postpartum periods for cows fed different diets throughout the dry period.

\begin{tabular}{|c|c|c|c|c|c|c|}
\hline \multirow[b]{2}{*}{ Variable } & \multicolumn{3}{|c|}{$\operatorname{Diet}^{1}$} & \multirow[b]{2}{*}{ SEM } & \multicolumn{2}{|c|}{ Contrasts $(P)$} \\
\hline & $\mathrm{C}$ & $\mathrm{F}$ & $\mathrm{CF}$ & & $\mathrm{C}$ vs. $\mathrm{CF}$ & C vs. F \\
\hline \multicolumn{7}{|c|}{ Insulin, $\mu \mathrm{IU} / \mathrm{mL}$} \\
\hline Prepartum $^{2}$ & 9.7 & 10.6 & 11.8 & 1.4 & 0.11 & 0.48 \\
\hline Transition $^{3}$ & 7.0 & 8.2 & 8.9 & 1.3 & 0.08 & 0.29 \\
\hline Postpartum $^{4}$ & 7.4 & 8.5 & 8.3 & 1.0 & 0.31 & 0.21 \\
\hline \multicolumn{7}{|l|}{ Glucose, mg/dL } \\
\hline Prepartum & 67.8 & 67.2 & 67.4 & 0.9 & 0.76 & 0.63 \\
\hline Transition & 62.4 & 62.2 & 62.8 & 1.3 & 0.92 & 0.80 \\
\hline Postpartum & 63.7 & 63.5 & 64.8 & 1.5 & 0.59 & 0.92 \\
\hline \multicolumn{7}{|l|}{ NEFA, $\mathrm{m} M$} \\
\hline Prepartum & 0.17 & 0.17 & 0.17 & 0.06 & 0.86 & 0.89 \\
\hline Transition & 0.58 & 0.67 & 0.61 & 0.19 & 0.62 & 0.45 \\
\hline Postpartum & 0.43 & 0.33 & 0.36 & 0.12 & 0.40 & 0.29 \\
\hline \multicolumn{7}{|l|}{ BHBA, mg/dL } \\
\hline Prepartum & 4.03 & 3.59 & 3.41 & 0.21 & 0.14 & 0.04 \\
\hline Transition & 7.44 & 8.31 & 5.84 & 1.00 & 0.55 & 0.26 \\
\hline Postpartum & 5.58 & 6.32 & 4.86 & 0.64 & 0.43 & 0.41 \\
\hline \multicolumn{7}{|c|}{ Cholesterol, mg/dL } \\
\hline Prepartum & 96.9 & 139.7 & 142.8 & 6.4 & 0.0001 & 0.0001 \\
\hline Transition & 76.3 & 107.2 & 114.2 & 5.3 & 0.0001 & 0.0004 \\
\hline Postpartum & 156.2 & 160.6 & 168.0 & 8.1 & 0.29 & 0.72 \\
\hline \multicolumn{7}{|c|}{ Total protein, $\mathrm{g} / \mathrm{dL}$} \\
\hline Prepartum & 8.36 & 8.47 & 8.55 & 0.24 & 0.35 & 0.58 \\
\hline Transition & 8.25 & 7.94 & 8.21 & 0.28 & 0.13 & 0.18 \\
\hline Postpartum & 8.74 & 8.62 & 8.73 & 0.27 & 0.98 & 0.61 \\
\hline \multicolumn{7}{|l|}{ Urea $\mathrm{N}, \mathrm{mg} / \mathrm{dL}$} \\
\hline Prepartum & 9.9 & 11.6 & 10.8 & 1.0 & 0.25 & 0.04 \\
\hline Transition & 10.0 & 11.1 & 10.9 & 1.3 & 0.29 & 0.21 \\
\hline Postpartum & 12.7 & 13.9 & 13.7 & 1.1 & 0.08 & 0.06 \\
\hline
\end{tabular}

${ }^{1} \mathrm{C}=$ Moderate NFC; $\mathrm{F}=$ low NFC, fat-supplemented; $\mathrm{CF}=$ moderate NFC, fat-supplemented.

${ }^{2}$ Mean for $\mathrm{d}-60$ to -1 .

${ }^{3}$ Mean for d -21 to 21 .

${ }^{4}$ Mean for d 1 to 105 .

vs. CF, $P<0.08)$. Lack of differences in these metabolic variables likely is explained by the generally similar intakes of $\mathrm{NE}_{\mathrm{L}}$ among diets.

Supplementing fat $(\mathrm{CF}, \mathrm{F})$ in the dry period diet increased concentrations of cholesterol in plasma during the prepartum and transition periods, regardless of the difference in caloric density between $\mathrm{C}$ and $\mathrm{CF}$ (Table 7). Postpartum cholesterol concentrations did not differ when all cows received the same diet, but increased from parturition to the end of the experiment (data not shown). Feeding diets containing supplemental fat (Palmquist and Conrad, 1978; Wrenn et al., 1978) or infusion of LCFA into the abomasum of lactating dairy cows (Drackley et al., 1992; Bremmer et al, 1998) has been shown to increase the concentrations of cholesterol in blood, which probably results from a greater demand for cholesterol in digestion, absorption, and transport of increased amounts of LCFA reaching the small intestine.

The concentration of total protein in plasma did not differ among dietary treatments, in agreement with
Kunz et al. (1985), who reported no differences in total protein in plasma of cows that were fed to meet or exceed requirements during the dry period. Concentrations of urea in plasma from cows fed $\mathrm{F}$ were higher during the dry period than those for cows fed $\mathrm{C}$ (Table 7). Differences might reflect slightly decreased amounts of readily fermentable carbohydrate available for bacterial protein synthesis (Clark et al., 1992), which could allow more $\mathrm{N}$ to escape the rumen in the form of ammonia for conversion to urea in the liver, or alterations in microbial populations in response to supplemental fat, which might result in decreased ammonia incorporation. Of interest, but unexplained, is that the lower plasma urea concentration for cows fed $\mathrm{C}$ during the dry period persisted after parturition when all cows were switched to the same lactation diet (Table 7).

Although most of the TG that accumulates in liver during the periparturient period arises from hepatic uptake of NEFA mobilized from adipose tissue (Grummer, 1995; Drackley et al., 2001), some LCFA originating from the diet can enter the liver by specific pathways 
(Grum et al., 1996a; Drackley, 1999). Indeed, supplemental dietary fat during the mid and late stages of lactation has been associated with increases in the TG content of liver during the subsequent transition period (Vazquez-Añon et al., 1997). Skaar et al. (1989) reported that supplementing fat in the diet from $17 \mathrm{~d}$ before expected parturition through early lactation tended to increase concentrations of total lipid and TG in liver tissue at $\mathrm{d} 1$ and wk 5 postpartum. In contrast, Grum et al. (1996b) demonstrated marked decreases in concentrations of total lipid and TG in liver tissue immediately postpartum after feeding supplemental fat throughout the dry period.

In contrast to these previous findings, concentrations of total lipid (Figure 3A) and TG (Figure 3B) in liver tissue at $d 1$ postpartum did not differ among treatments, and interactions of diet $\times$ day did not approach significance. Additionally, no difference among treatment groups was observed for concentrations of glycogen (Figure 3C) in liver tissue throughout the prepartum and postpartum periods. Concentrations of total lipid and TG increased (day; $P<0.0001$ ), whereas concentrations of glycogen decreased (day; $P<0.0001$ ) from $\mathrm{d}-21$ to 1 relative to calving irrespective of diets fed throughout the dry period (Figure 3). Others have reported similar increases in liver lipid accumulation that accompanied peripartal increases in concentrations of NEFA in plasma (Skaar et al., 1989; Bertics et al., 1992; Vasquez-Ãnon et al., 1994). By d 65 postpartum, concentrations of total lipid, TG, and glycogen in liver had returned to those observed at $-65 \mathrm{~d}$ relative to calving.

Grum et al. (1996b) reported that the lower DMI for cows fed a fat-supplemented diet resulted in loss rather than gain of BCS during the dry period when compared with nonlactating cows fed an isocaloric high-grain diet or control diet. Peripartal lipid accumulation in liver tissue was significantly decreased for cows fed supplemental fat despite the increased concentrations of NEFA in plasma during the dry period. In that study, fat replaced primarily starch; in the present study, that situation would be reflected in diet F. On the basis of our data reported here, however, the marked decreases in peripartal concentrations of total lipid and TG in liver observed previously (Grum et al., 1996b) seem unlikely to be attributable directly to the supplemental fat used in that study.

Drackley (1999) and Rukkwamsuk et al. (1998) have proposed that alterations in liver metabolism might adapt the ruminant liver to contend with the large peripartal increases in blood NEFA and minimize the risk for the development of fatty liver. Indeed, Grum et al. (1996b) attributed distinct decreases in peripartal lipid accumulation in liver to the higher ratios of peroxisomal
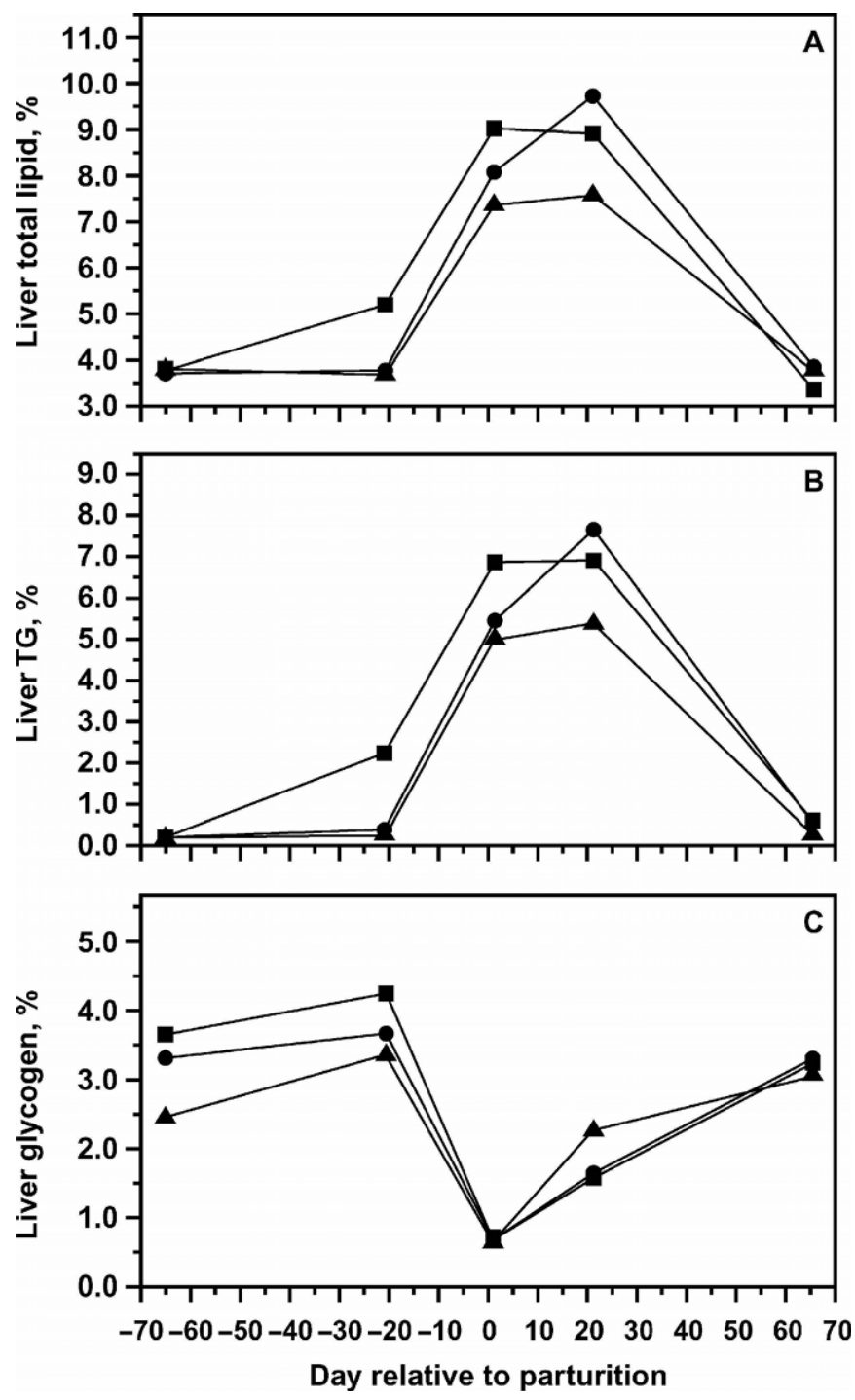

Figure 3. Concentrations (wet weight basis) of total lipid (A), triglyceride (TG; B), and glycogen (C) in liver from cows fed a control, moderate NFC diet $(\mathrm{C} ; \mathbf{\square})$, a low NFC diet supplemented with fat $(\mathrm{F} ; \boldsymbol{\Delta})$, or a moderate NFC diet supplemented with fat (CF; $)$ during the dry period. A) Pooled SEM $=1.12 \%$. Effects in the model included $\mathrm{C}$ vs. CF $(P=0.75), \mathrm{C}$ vs. F $(P=0.24)$, day $(P<0.0001)$, and the interaction of diet and day $(P=0.80)$. B) Pooled SEM $=1.26 \%$. Effects in the model included $\mathrm{C}$ vs. $\mathrm{CF}(P=0.52), \mathrm{C}$ vs. F $(P=0.17)$, day $(P$ $<0.0001)$, and the interaction of diet and day $(P=0.86)$. C) Pooled $\mathrm{SEM}=0.48 \%$. Effects in the model included $\mathrm{C}$ vs. $\mathrm{CF}(P=0.71), \mathrm{C}$ vs. $\mathrm{F}(P=0.73)$, day $(\mathrm{P}<0.0001)$, and the interaction of diet and day $(P=0.56)$

to total $\beta$-oxidation and to lower in vitro rates of palmitate esterification in liver tissue after exposure to higher concentrations of NEFA in plasma throughout the dry period. Additionally, lower concentrations of insulin in plasma during the dry period might decrease the activities of pathways involved in the esterification and accumulation of LCFA in ruminant liver tissue. 
Grum et al. (1996b) reported that concentrations of insulin and glucose decreased while concentrations of NEFA increased in plasma obtained during the dry period from cows with lower lipid accumulation in liver tissue at calving. Rukkwamsuk et al. (1998) reported decreased peripartal accumulation of lipid in liver tissue from cows with decreased insulin concentrations in plasma because of restricted energy intake during the dry period. Although insulin is associated with increases in TG formation in rodent liver (Beyen et al., 1981; Cappello and Gnoni, 1994), the effects of insulin on the ability of ruminant liver to esterify LCFA are not fully understood (Drackley et al., 2001).

Alternatively, the decreased DMI, loss of BW, decreased insulin, and increased NEFA in plasma from pregnant nonlactating cows in the study of Grum et al. (1996b) indicate that those cows were in a state of negative energy balance throughout the dry period. The alterations in hepatic lipid metabolism may have resulted from a combination of physiological changes in response to the prolonged state of negative energy balance during the dry period. Indeed, results of a companion study conducted concurrently with the present study indicate that lower nutrient intake prepartum likely was the factor responsible for the prevention of lipid accumulation (Douglas, 2002). In the study reported here, similar intakes of DM and energy and similar concentrations of insulin in plasma among the treatment groups throughout the dry period could explain the lack of differences in peripartum lipid accumulation in liver. The exact mechanism(s) involved with the changes in peripartal liver lipid metabolism observed previously by Grum et al. (1996b) are not yet fully understood.

\section{CONCLUSIONS}

Supplemental fat during the dry period did not decrease peripartal lipid accumulation in liver in this study as observed by Grum et al. (1996b) when cows were fed the same fat source during the dry period. In the earlier study (Grum et al., 1996b), marked decreases in total lipid and TG accumulation in liver were observed immediately postpartum in cows that were fed a fat-supplemented diet formulated to add BCS during the dry period. The decreases in DMI and losses of BCS by cows offered that diet confounded the effects of feeding supplemental fat during the dry period. On the basis of our results, we suggest that the alterations in liver lipid metabolism at calving observed by Grum et al. (1996b) were more likely the result of decreased insulin and increased NEFA in plasma in response to decreased DMI and negative energy balance experi- enced by cows that were fed supplemental fat during the dry period.

Regardless, based on our data, we suggest that there is little clear benefit (or detriment) to peripartal health and postpartum performance from adding fat to diets for dry cows. However, no control diet with caloric density meeting NRC specifications for dry cows (1.25 Mcal/ $\mathrm{kg}$; NRC, 1989, 2001) was fed to allow a comparison with performance of cows fed above NRC standards as in this experiment $(\mathrm{C}$ and $\mathrm{F}, 1.46 \mathrm{Mcal} / \mathrm{kg}$; CF, 1.60 $\mathrm{Mcal} / \mathrm{kg}$ ). Interactions of diet and day suggested that CF may have facilitated a slower decrease in DMI and maintenance of higher $\mathrm{NE}_{\mathrm{L}}$ intake during the last $3 \mathrm{wk}$ before parturition, and tended to result in less loss of BCS and BW postpartum. Although intriguing, these results should be verified with larger numbers of cows. Our results were obtained with cows fed essentially the same diets throughout the entire dry period, rather than a 2-diet (i.e., far-off and close-up) approach. Responses to fat supplementation might be different if incorporated only for 2 to $3 \mathrm{wk}$ preceding parturition. Moreover, caution should be exercised when increasing the caloric density of any diet fed for prolonged amounts of time during the dry period because overfeeding and overconditioning might increase the risk for peripartal health disorders, especially in cows with greater BCS than those in the present study.

\section{ACKNOWLEDGMENTS}

The authors extend appreciation to G. C. McCoy and employees of the University of Illinois Dairy Research and Teaching Unit for provision and care of cows. Soybean hulls were donated by Archer Daniels Midland Co. (Decatur, IL).

\section{REFERENCES}

Allain, C. C., L. S. Poon, C. S. Chan, W. Richmond, and P. C. Fu. 1974. Enzymatic determination of total serum cholesterol. Clin. Chem. 20:470-475.

Association of Official Analytical Chemists. 1990. Official Methods of Analysis. Vol. I. 15th ed. AOAC, Arlington, VA.

Bertics, S. J., R. R. Grummer, D. Cadorniga-Valino, and E. E. Stoddard. 1992. Effect of prepartum dry matter intake on liver triglyceride concentration in early lactation. J. Dairy Sci. 75:1914-1922.

Beyen, A. C., H. P. Haagsman, L. M. G. Van Golde, and M. J. H. Geelen. 1981. The effects of insulin and glucagon on the release of triacylglycerols by isolated rat hepatocytes are mere reflections of the hormonal effects on the rate of triacylglycerol synthesis. Biochim. Biophys. Acta 665:1-7.

Bremmer, D. R., L. D. Ruppert, J. H. Clark, and J. K. Drackley. 1998. Effects of chain length and unsaturation of fatty acid mixtures infused into the abomasum of lactating dairy cows. J. Dairy Sci. 81:176-188.

Cameron, R. E. B., P. B. Dyk, T. H. Herdt, J. B. Kaneene, R. Miller, H. F. Bucholtz, J. S. Liesman, M. J. VandeHaar, and R. S. Emery. 1998. Dry cow diet, management, and energy balance as risk factors for displaced abomasum in high producing dairy herds. J. Dairy Sci. 81:132-139. 
Cappello, A. R., and G. V. Gnoni. 1994. Influence of triiodothyronine and insulin on the synthesis of glycerolipids in rat hepatocytes. Biochem. Mol. Biol. Int. 34:101-107.

Clark, J. H., T. H. Klusmeyer, and M. R. Cameron. 1992. Microbial protein synthesis and flows of nitrogen fractions to the duodenum of dairy cows. J. Dairy Sci. 75:2304-2323.

Crocker, C. L. 1967. Rapid determination of urea nitrogen in serum or plasma without deproteinization. Am. J. Med. Technol. 33:361-365.

Domecq, J. J., A. L. Skidmore, J. W. Lloyd, and J. B. Kaneene. 1997. Relationship between body condition scores and milk yield in large dairy herd of high yielding Holstein cows. J. Dairy Sci. 80:101-112.

Douglas, G. N. 2002. Peripartal lipid metabolism and tissue fatty acid composition in Holstein cows fed supplemental fat during the dry period. Ph.D. Diss., Univ. Illinois, Urbana.

Drackley, J. K. 1999. Biology of dairy cows during the transition period: The final frontier? J. Dairy Sci. 82:2259-2273.

Drackley, J. K., T. H. Klusmeyer, A. M. Trusk, and J. H. Clark. 1992. Infusion of long-chain fatty acids varying in saturation and chain length into the abomasum of lactating dairy cows. J. Dairy Sci. 75:1517-1526.

Drackley, J. K., T. R. Overton, and G. N. Douglas. 2001. Adaptations of glucose and long-chain fatty acid metabolism in liver of dairy cows during the periparturient period. J. Dairy Sci. 84:E100E112.

Drackley, J. K., J. J. Veenhuizen, M. J. Richard, and J. W. Young. 1991. Metabolic changes in blood and liver of dairy cows during either feed restriction or administration of 1,3-butanediol. J. Dairy Sci. 74:4254-4264.

Emery, R. S., J. S. Liesman, and T. H. Herdt. 1992. Metabolism of long chain fatty acids by ruminant liver. J. Nutr. 122:832-837.

Foster, L. B., and R. T. Dunn. 1973. Stable reagents for the determination of serum triglyceride by a colorimetric Hantzsch condensation method. Clin. Chem. 19:338-340.

Fronk, T. J., L. H. Schultz, and A. R. Hardie. 1980. Effects of dry period overconditioning on subsequent metabolic disorders and performance of dairy cows. J. Dairy Sci. 63:1080-1090.

Grum, D. E., J. K. Drackley, L. R. Hansen, and J. D. Cremin, Jr. 1996a. Production, digestion, and hepatic lipid metabolism of dairy cows fed increased energy from fat or concentrate. J. Dairy Sci. 79:1836-1849.

Grum, D. E., J. K. Drackley, R. S. Younker, D. W. LaCount, and J. J. Veenhuizen. 1996b. Nutrition during the dry period and hepatic lipid metabolism of periparturient dairy cows. J. Dairy Sci. 79:1850-1864.

Grummer, R. R. 1993. Etiology of lipid-related metabolic disorders in periparturient dairy cows. J. Dairy Sci. 76:3882-3896.

Grummer, R. R. 1995. Impact of changes in organic nutrient metabolism on feeding the transition cow. J. Anim. Sci. 73:2820--2833.

Johnson, M. M., and J. P. Peters. 1993. Technical note: An improved method to quantify nonesterified fatty acids in bovine plasma. J. Anim. Sci. 71:753-756.

Keady, T. W. J., C. S. Mayne, D. A. Fitzpatrick, and M. A. McCoy. 2001. Effect of concentrate feed level in late gestation on subsequent milk yield, milk composition, and fertility of dairy cows. J. Dairy Sci. 84:1468-1479.

Kunz, P. L., J. W. Blum, I. C. Hart, H. Bickel, and J. Landis. 1985. Effects of different energy intakes before and after calving on food intake, performance and blood hormones and metabolites in dairy cows. Anim. Prod. 40:219-231.

Lo, S., J. C. Russell, and A. W. Taylor. 1970. Determination of glycogen in small tissue samples. J. Appl. Physiol. 28:234-236.
Morris, T. R. 1999. Pages 31-41 in Experimental Design and Analysis in Animal Sciences. CABI Publishing, Wallingford, UK.

Morrow, D. A. 1976. Fat cow syndrome. J. Dairy Sci. 59:1625-1629.

National Research Council. 1989. Nutrient Requirements of Dairy Cattle. 6th rev. ed. National Academy Press, Washington, DC.

National Research Council. 2001. Nutrient Requirements of Dairy Cattle. 7th rev. ed. National Academy Press, Washington, DC.

Otto, K. L., J. D. Ferguson, D. G. Fox, and C. J. Sniffen. 1991. Relationship between body condition score and composition of ninth to eleventh rib tissue in Holstein dairy cows. J. Dairy Sci. 74:852-859.

Palmquist, D. L., and H. R. Conrad. 1978. High fat rations for dairy cows. Effects on feed intake, milk and fat production, and plasma metabolites. J. Dairy Sci. 61:890-901.

Reid, I. M., C. J. Roberts, R. J. Treacher, and L. A. Williams. 1986. Effect of body condition at calving on tissue mobilization, development of fatty liver and blood chemistry of dairy cows. Anim. Prod. 43:7-15.

Rukkwamsuk, T., T. Wensing, and M. J. H. Geelen. 1998. Effect of overfeeding during the dry period on regulation of adipose tissue metabolism in dairy cows during the periparturient period. J. Dairy Sci. 81:2904-2911.

SAS User's Guide: Statistics, Version 7 Edition. 1998. SAS Inst., Inc. Cary, NC.

Skaar, T. C., R. R. Grummer, M. R. Dentine, and R. H. Stauffacher. 1989. Seasonal effects of prepartum and postpartum fat and niacin feeding on lactation performance and lipid metabolism. J. Dairy Sci. 72:2028-2038.

Studer, V. A., R. R. Grummer, and S. J. Bertics. 1993. Effect of prepartum propylene glycol administration on periparturient fatty liver in dairy cows. J. Dairy Sci. 76:2931-2939.

Sukhija, P. S., and D. L. Palmquist. 1988. Rapid method for determination of total fatty acid content and composition of feedstuffs and feces. J. Agric. Food Chem. 36:1202-1206.

Treacher, R. J., I. M. Reid, and C. J. Roberts. 1986. Effect of body condition at calving on the health and performance of dairy cows. Anim. Prod. 43:1-6.

Trinder, P. 1969. Determination of blood glucose using 4-amino phenazone as oxygen acceptor. Clin. Pathol. 22:246.

VandeHaar, M. J., G. Yousif, B. K. Sharma, T. H. Herdt, R. S. Emery, M. S. Allen, and J. S. Liesman. 1999. Effect of energy and protein density of prepartum diets on fat and protein metabolism of dairy cattle in the periparturient period. J. Dairy Sci. 82:1282-1295.

Vazquez-Añon, M., S. J. Bertics, and R. R. Grummer. 1997. The effect of dietary energy source during mid to late lactation on liver triglyceride and lactation performance of dairy cows. J. Dairy Sci. 80:2504-2512.

Vazquez-Añon, M., S. Bertics, M. Luck, R. R. Grummer, and J. Pinheiro. 1994. Peripartum liver triglyceride and plasma metabolites in dairy cows. J. Dairy Sci. 77:1521-1528.

Weichselbaum, T. E. 1945. An accurate and rapid method for the determination of proteins in small amounts of blood serum and plasma. Am. J. Clin. Pathol. 16:40-49.

Wildman, E. E., G. M. Jones, P. E. Wagner, R. L. Boman, H. F. Troutt, and T. N. Lesch. 1982. A dairy cow body condition scoring system and its relationship to selected production characteristics. J. Dairy Sci. 65:495-501.

Williamson, D. H., and J. Mellanby. 1974. D-(-)-3-hydroxybutyrate. Pages 1836-1840 in Methods of Enzymatic Analysis. Vol. 4. H. U. Bergmeyer, ed. Academic Press, London, UK.

Wrenn, T. R., J. Bitman, R. A. Waterman, J. R. Weyant, D. L. Wood, L. L. Strozinski, and N. W. Hooven, Jr. 1978. Feeding protected and unprotected tallow to lactating cows. J. Dairy Sci. 61:49-58. 